\title{
Peran dan Fungsi E-Bisnis Dalam Bisnis Digital.
}

Nama : FAKHRUL IKHTIAR GHIFARI

Npm : 195100009

Prodi : Sistem Informasi Sore

${ }^{1}$ Faculty Of Computer Universitas Mitra Indonesia Fakhrulikhtiar.student@umitra.ac.id

\section{UTS E-bisnis}

1. Jelaskan Dalam jawaban bentuk artikel submit osf. Dengan Judul " Peran dan Fungsi E-Bisnis Dalam Bisnis Digital.

Jawab ;

\section{Peran dan Fungsi E-Bisnis Dalam Bisnis Digital.}

Dalam dunia bisnis peranan Teknologi Informasi dimanfaatkan untuk perdagangan secara elektronik atau dikenal sebagai E-Commerce (e-dagang) atau perdagangan elektronik. ECommerce adalah perdagangan menggunakan jaringan komunikasi internet. E-commerce merupakan bagian dari e-business, di mana cakupan e-business lebih luas, tidak hanya sekedar perniagaan tetapi mencakup juga pengkolaborasian mitra bisnis, pelayanan nasabah, lowongan pekerjaan dan lain-lain. Selain teknologi jaringan www, e-dagang juga memerlukan teknologi basis data atau pangkalan data (databases), e-surat atau surat elektronik (e-mail), dan bentuk teknologi non komputer yang lain seperti halnya sistem pengiriman barang, dan alat pembayaran untuk e-dagang ini.

\section{Mempermudah Cara Komunikasi}

Bagi banyak perusahaan, email adalah sarana utama komunikasi antara karyawan, pemasok dan pelanggan. Email adalah salah satu pendorong awal Internet, Penggunaannya sangat mudah dan relatif jauh lebih murah jika dibandingkan dengan faksimile untuk berkomunikasi.Selama bertahun-tahun, sejumlah alat komunikasi lainnya juga berkembang, yang memungkinkan para staf untuk saling berkomunikasi dengan menggunakan sistem chat (chatting), alat pertemuan online dengan sistem konferensi video seperti webinar, Voice over internet protocol (VOIP) dan masih banyak lagi lainnya.

2. Memberikan Pengetahuan dan Sumber Informasi

Melalui internet, anda hanya membutuhkan satu klik dan semua informasi sudah tersedia di depan mata Anda. Semakin banyak pengetahuan yang anda peroleh mengenai bisnis, maka semakin berkembang pula bisnis yang sedang anda kelola. Selain itu anda dapat dengan mudah untuk mencari informasi yang berkaitan dengan kompetitor anda. 


\section{Manajemen Data}

Deretan lemari arsip yang berisikan dokumen-dokumen perusahaan sekarang sudah tidak terlalu dibutuhkan lagi oleh beberapa perusahaan, dengan adanya database. Saat ini, sebagian besar perusahaan menyimpan versi digital dari dokumen pada server dan perangkat penyimpanan. Dokumen-dokumen ini menjadi langsung tersedia bagi semua orang di perusahaan, terlepas dari lokasi geografis mereka. Perusahaan yang mampu menyimpan dan memelihara sejumlah besar data historis secara ekonomis, dan karyawan dapat mengakses langsung dokumen yang mereka butuhkan.

\section{Sistem Informasi Manajemen}

Menyimpan data hanya menguntungkan jika data yang dapat digunakan secara efektif. Perusahaan progresif menggunakan data itu sebagai bagian dari proses perencanaan strategis serta pelaksanaan taktis dari strategi itu. Sistem Informasi Manajemen (SIM) memungkinkan perusahaan untuk melacak data penjualan, biaya dan tingkat produktivitas. Informasi ini dapat digunakan untuk melacak profitabilitas dari waktu ke waktu, memaksimalkan laba atas investasi dan mengidentifikasi bidang yang perlu perbaikan. Manajer dapat melacak penjualan setiap hari, yang memungkinkan mereka untuk segera bereaksi terhadap angka yang lebih rendah dari perkiraan dengan meningkatkan produktivitas karyawan atau mengurangi biaya item.

\section{Customer Relationship Management}

Perusahaan menggunakan TI untuk memperbaiki cara mereka merancang dan mengelola hubungan terhadap pelanggan. Customer Relationship Management (CRM) sebuah sistem yang dapat menangkap setiap interaksi perusahaan terhadap para pelanggan, sehingga terdapat data kronologis pelanggan jika sewaktu-waktu dibutuhkan, bagaikan data record. Salah satu contohnya pelanggan menghubungi call center karena mendapatkan masalah, mengenai informasi pengiriman barang yang ia pesan. Dengan adanya CRM staff perusahaan dapat segera memberitahukan keberadaan barang pesanan pelanggan. Karena seluruh interaksi disimpan dalam sistem CRM. Pelanggan pun menjadi tenang, karena mendapatkan pelayanan yang memuaskan, Hal ini memberikan keuntungan bagi perusahaan sehingga dapat lebih meningkatkan kinerja terhadap produktivitas.

\section{Aktivitas Bisnis Selama 24 Jam}

Dengan adanya perkembangan teknologi informasi sangat membantu para pelaku bisnis untuk melakukan aktivitas jual beli selama 24 jam, tidak seperti toko offline yang segala aktivitasnya sangat dibatasi oleh ruang dan waktu Seiring dengan berkembang pesatnya ilmu pengetahuan dan teknologi, Para pelaku IT mulai gencar memanfaatkan kemajuan tersebut. Khususnya dalam bidang Teknologi Informasi, para pelaku IT dapat memperoleh kemudahan dalam setiap urusannya. Dunia bisnis sudah sangat kompetitif dimana ada banyak persaingan untuk dapat terus berkembang. Diperlukan kreativitas, kegigihan, dan pengetahuan yang maju agar bisa bersaing di dalamnya. 
2. Jelaskan Proses dalam E-bisnis berkaitan secara menyeluruh dengan proses bisnis lainnya, seperti : ( Nilai 50 )

1. Value chain adalah serangkaian kegiatan bisnis yang mana pada setiap tahapan atau langkahnya mampu meningkatkan nilai atau pemanfaatan pada barang atau jasa yang diproduksi

2. Manajemen Rantai Pasok adalah sebuah proses yang terpadu dan jelas. Fungsinya untuk membantu memberikan informasi kepada manajemen mengenai pengadaan barang. Tak hanya itu saja, sistem ini juga memuat informasi mengenai hubungan dengan pihak luar seperti vendor atau supplier.

3. Pemrosesan order elektronik adalah dokumen yang dihasilkan oleh penjual setelah menerima pesanan pembelian dari pembeli yang menetapkan rincian produk atau layanan beserta harga, kuantitas, detil pembeli seperti alamat pengiriman, alamat penagihan, jenis pembayaran beserta syarat

4. Customer service pastinya harus bisa melihat permasalahan yang ada, kemudian menganalisis mengapa keluhan tersebut dapat terjadi. Jika keluhan pelanggan tidak segera diatasi dengan baik, maka hal ini dapat memberikan masalah di kemudian hari

5. Business partnership atau kemitraan bisnis adalah hubungan hukum yang dibentuk oleh kesepakatan antara dua orang atau lebih untuk menjalankan bisnis sebagai pemilik bersama. Kemitraan adalah bisnis dengan 
3. Jelaskan Dalam kegiatan e-bisnis, ada lima kemungkinan bentuk hubungan bisnis berdasarkan transaksinya, yaitu : ( Nilai 50 )

\section{Business to Consumers}

Ini adalah jenis e commerce yang paling terkenal, khususnya di Indonesia. Dimana produsen atau perusahaan (pihak penjual), memasarkan produk secara langsung. Dengan customer (pengguna) sebagai mangsa pasar. Jadi, di ibaratkan seperti toko ritel berbasis online. Dimana pembeli bisa membeli produk secara eceran, tanpa jumlah minimal tertentu.

\section{Consumer to Business}

Dalam jenis consumer to business, transaksi penjualan dilakukan oleh pihak konsumen. Sedangkan perusahaan adalah target pasarnya. Jadi, individu memberikan penawaran mengenai sebuah produk berupa barang atau jasa. Kepada perusahaan-perusahaan yang memang membutuhkan. Misalnya saja desainer grafis yang menawarkan skill-nya.

\section{Consumer to Consumer}

Jenis e commerce ini dilakukan dari konsumen ke konsumen. Klasifikasinya terdiri dari 2 model, yaitu classifed dan marketplace. Kalau dalam classified, buyer dan seller melakukan transaksi secara langsung. Sedangkan dalam marketplace, konsumen (penjual) memerlukan platform untuk tempat melakukan transaksi. Contoh marketplace, adalah Shopee.

\section{Business to Administration}

Pada jenis e commerce ini, pelaku bisnis menjual produk barang atau pun jasa dengan menjadikan lembaga pemerintahan sebagai pasar. Transaksi yang dilakukan juga dalam bentuk tender.

\section{Online to Offline}

Di zaman modern sekarang ini, jenis e commerce satu ini sangat populer. Dimana pihak seller melakukan kegiatan promosi, mencari pembeli, dan menyediakan produk dengan memanfaatkan jaringan online sebagai media. Namun pembeli memiliki option untuk dapat belanja langsung di toko offline 